\title{
Coral transplant damage under various management conditions in the Mombasa Marine National Park, Kenya
}

\author{
Annick $\operatorname{Cros}^{1}$ and Tim McClanahan ${ }^{2}$ \\ ${ }^{1}$ University of Newcastle upon Tyne, Department of Marine Sciences and Coastal Management, Ridley \\ Building, University of Newcastle, Newcastle upon Tyne NE1 7RU, UK; \\ ${ }^{2}$ The Wildlife Conservation Society, Coral Reef Conservation Project, P.O. Box 99470, Mombasa,Kenya
}

\begin{abstract}
Key words: beach seining, corallivory, fishing gear, marine protected areas, Porites, reef management, reef rehabilitation, Kenya

Abstract-Two coral species, Porites palmata and Porites lutea, were transplanted into three distinct management areas adjacent to the Mombasa Marine National Park, Kenya: A no-fishing MPA; a gear-restricted reserve with no beach seining; and a reserve with beach seining. Corallivory by fish or breakage by fishing gear was measured over a 57-day period. Porites palmata, the branching species, was more susceptible to disturbance than Porites lutea, the massive species, which showed no difference in mortality rate between the three management areas. Porites palmata was affected more by corallivory than fishing gear and, therefore, suffered more damage from coral predators in the no-fishing MPA. Corals transplanted into the gearrestricted fishing site had the highest survival. The damage from predators was small and seldom resulted in total colony mortality, which was common in the fishing area with beach seining.
\end{abstract}

\section{INTRODUCTION}

Kenya's marine resources are under increasing pressure from over-exploitation (Obura, 2001). Kenya has four marine parks, some of them in place for more than 20 years (McClanahan \& Mangi, 2001), but to a large extent its reefs are not regulated and destructive fishing gear such as beach seines are commonly used. The beach seines are approximately $150 \mathrm{~m}$ in length with a mesh of approximately $3 \mathrm{~cm}$ and are dragged across seagrass, sand and coral reef substrata, causing direct physical damage to the reefs. This damage could indirectly influence fish stocks (Jennings \& Polunin, 1996; Jennings \& Kaiser, 1998; McClanahan \& Mangi, 2001). The nets are detrimental to fish populations due to their mesh size and non-selectivity (Jennings \& Kaiser, 1998). Fish density and diversity are positively correlated with reef complexity and live coral cover (Bell \&
Galzin, 1984; McClanahan \& Shafir, 1990; McClanahan, 1994a; Chabanet et al., 1997; Jennings \& Polunin, 1996) and damage to the reefs could indirectly influence fish communities.

Marine protected areas have been advocated as an effective management tool because they offer protection not provided by other management strategies. These include specific protection of critical areas, the conservation of biological diversity, prevention of over fishing and even the enhancement of fisheries (Allison et al., 1998). Since its establishment in 1988 the Mombasa Marine National Park (MMNP) has exhibited an increase in fish and live coral cover (McClanahan $\&$ Arthur, 2001). An increase in fish can, however, have indirect effects on coral by increasing corallivory, and this can result in the exclusion of certain predator-susceptible coral species (Cox, 1986; Miller \& Hay, 1998).

It is becoming increasingly difficult to

Corresponding author: AC.

E-mail: annick_c@yahoo.fr 
determine the different sources of damage to coral reefs. Nonetheless, in order to improve reef management and design strategies for reef conservation and rehabilitation, it is essential to understand the ramifications of the direct and indirect effects of various human activities. Past studies have measured the effect of beach seining by recording the decrease in catches and monitoring catch weight (McClanahan \& Mangi, 2001). A few studies have measured the direct effects of fishing gear on corals. Comparisons of substrata between protected and fished reefs have shown that unfished reefs have a higher reef topography (McClanahan, 1994a), but multiple factors could have influenced these results. Experimental methods must be used when evaluating fishing gear as the condition of corals is affected by many factors and complex interactions. Dusek (2000) attempted to measure the damage caused by beach seines on corals but recognised that some corals may have already been excluded from that study, leaving only the most tolerant species to be evaluated.

The aim of the experiments presented here was to use coral transplants and exclusion cages to measure the impact of beach seining on corals, comparing it with the damage found inside a marine park devoid of fishing, a marine reserve with high fishing pressure but no beach seining, and a site subject to beach seining.

\section{MATERIALS AND METHODS}

\section{Experimental sites}

The study was conducted on the fringing reef north of Mombasa City, Kenya (Fig. 1). Three sites were selected in back reef lagoons with shallow water ( $<3 \mathrm{~m}$ ) at low tide (Kenya has a $4 \mathrm{~m}$ tidal range), dominated by hard substratum colonised by corals, other benthic invertebrates and algae (McClanahan $\&$ Shafir, 1990). The no-fishing site was located in the Mombasa Marine National Park (MMNP). The park was established in 1988, and effective enforcement began in 1991. It has been categorised as a transitional park in most literature due both to its management and fish community characteristics (McClanahan, 1994a; Carreiro-Silva \& McClanahan, 2001; McClanahan \& Arthur, 2001). Like the majority of Kenyan coral reefs, it suffered extensive coral mortality during the 1998 El Niño bleaching event (McClanahan et al., 2001).

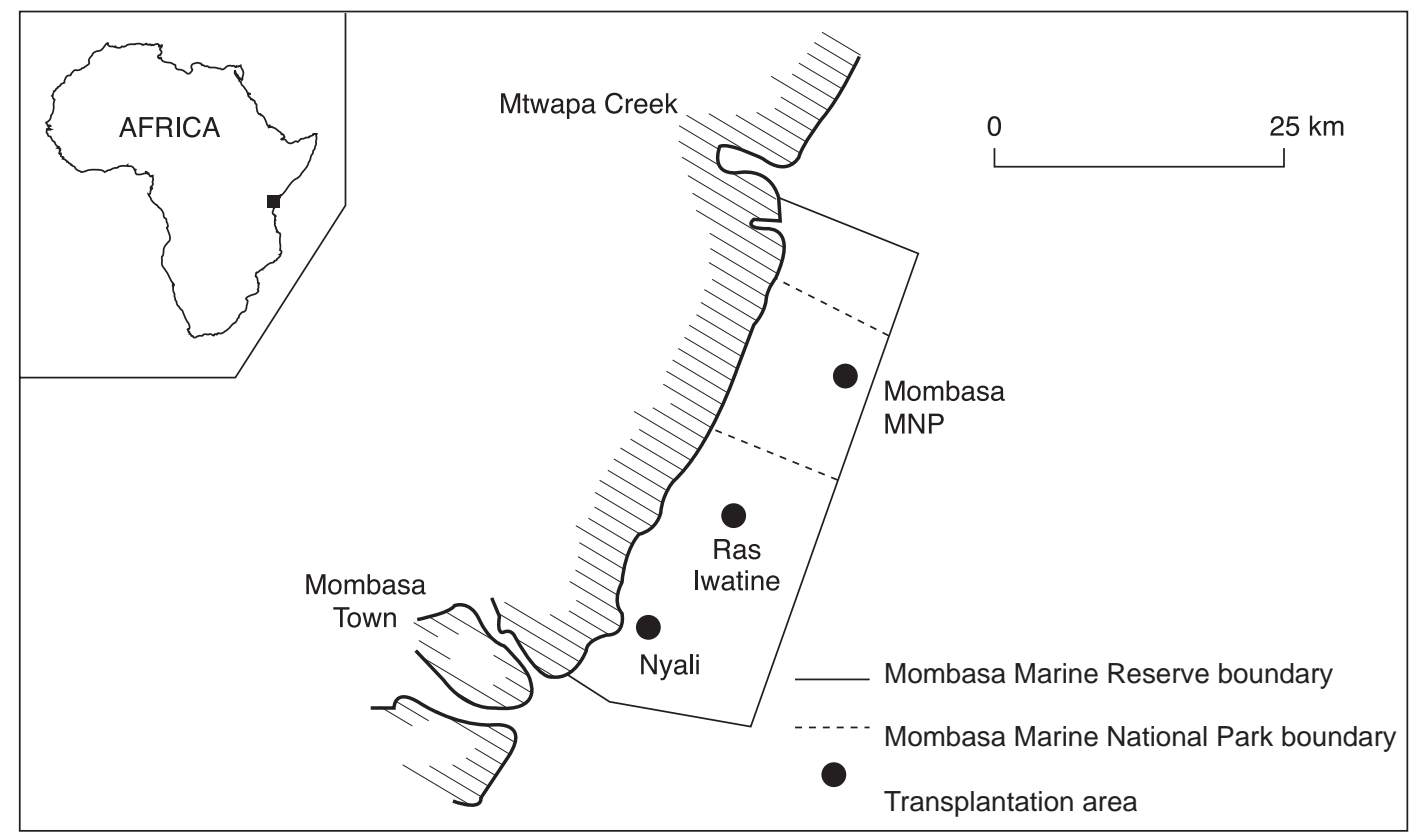

Fig. 1. Mombasa Marine Reserve and transplantation sites, Mombasa, Kenya 
A 'restricted fishing' site was located at Ras Iwatine, in the Mombasa Marine National Reserve. Although fishing there has recently been limited, excluding beach seining, this site is exposed to high fishing intensity (McClanahan \& Mangi, 2001). A 'beach seining' site was located offshore of Nyali Beach (Fig. 1). This site is within the Mombasa Marine National Reserve, but lacks enforcement (S. Mangi, pers. commun.), and all common fishing gears were used at this site. The transplantation area at this site was selected according to two criteria: the repeated observation of beach seining and the presence of hard substratum and coral heads.

\section{Reef condition}

The percentage cover of dominant benthic life forms was estimated at Nyali Beach using 10 randomly placed line-intercept transects of $10 \mathrm{~m}$ (McClanahan \& Shafir, 1990). Data from MMNP and Ras Iwatine were taken from a monitoring using the same methods but larger replication (12 transects in Ras Iwatine and 18 in MMNP) 5 months prior to this study.

\section{Transplantation}

\section{Donor site}

Branching Porites palmata and massive Porites lutea were collected from Kanamai reef, a lagoonal patch reef $20 \mathrm{~km}$ north of Mombasa. Differentsized fragments, ranging from finger size to large heads, were removed from the reef with a hammer and chisel. They were placed in buckets of seawater and transported on the same day by car and boat to MMNP where they were held under a large cage before being fixed to the substratum. Transport never took more than one and a half hours (40 minutes by car, 20 minutes by boat) and the coral fragments showed no signs of stress apart from the production of mucus.

\section{Transplantation}

When ready for transplantation, the corals were transported to the sites in buckets. The corals were randomly selected from the colonies held in the large cages for this purpose. Transportation never took longer than 40 minutes by boat. A total of 294 corals were transplanted at the three designated sites. They were fixed to wire-brushed, hard substratum or dead coral using cement in pairs, one branching and one massive species per pair, in 'blocks' of seven pairs. Each of the corals in a pair were around a half-metre apart and the pairs were about one metre from each other. Six such 'blocks' were fixed at MMNP and Ras Iwatine and nine at Nyali along compass bearings. The location of the blocks at each site was selected by looking for appropriate substratum for transplantation. Each fragment had 90-100\% live cover at the time of attachment.

\section{Cages}

Plastic mesh $(2.5 \mathrm{~cm})$ was used to construct control or predator-exclusion cages. Each cage was a halfcylinder shaped (length $60 \mathrm{~cm}$, height $21 \mathrm{~cm}$ ). The cages were fixed to the reef substratum with $U$ shaped nails, holding one pair of corals per cage and protecting one pair of corals per 'block'. The cages were fixed immediately after transplantation of the corals and were brushed twice a week to prevent algal overgrowth, and checked for looseness and repaired.

\section{Data collection}

The greatest length, width and height of the transplants were measured with metal callipers on the day following transplantation and again the last day of monitoring. Percent live cover was estimated for each coral and the type of damage was recorded in seven categories:

1. damage from transplantation,

2. predation by fish,

3. predation by corallivorous gastropods,

4. predation by Acanthaster planci (COT),

5. competition with sponges,

6. smothering by sand, and

7. damage from beach seining.

The determination of these categories was based on many hours of field observations of coral transplants and from previous unpublished studies. Estimates were made twice a week in MMNP and at Ras Iwatine and three times a week at Nyali. The measurements were terminated after 57 days. Measurement of percentage live cover was subjective, but undertaken throughout by the same 
observer and any sampling errors were presumably consistent. The caged corals were measured as controls.

\section{Statistical analysis}

For all the analyses, branching Porites palmata were treated separately from massive Porites lutea. Controls (caged corals) were not included in any of the statistics except when being compared with the experimental corals (non-caged). Measurement of the percentage live coral cover loss between the first measurement and the last measurement, i.e. 100 -([\% live cover last day - \% live cover 1 st day] $\mathrm{x} 100)$ was used as a measure of 'percentage mortality'. A mean was calculated for each species in each block at each site. This permitted the modelling of normal distributions according to the central distribution theory (Zar, 2000). Nevertheless, tests of normality were carried out and transformations were applied in case of strong deviations from normality. The data were not normally distributed, even after transformation and therefore the non-parametrical equivalent of the ttest was used. A one-tailed non-parametric MannWhitney $U$ test was carried out to determine if percentage mortality for the controls (corals in cages) was smaller than the experiments (corals outside cages).

The difference in the percentage mortality between sites was normally distributed and was tested with a one-way ANOVA. A post hoc Tukey test was carried out to compare specific management treatments. A two-way ANOVA was carried out to test for possible species versus site interactions. Differences in the relationship between size and percentage mortality were tested with an ANCOVA by coral size as a covariate. Coral measurements were converted to cubic volume by multiplying the length, width and height taken from the first measurements. Natural log transformations were performed on both size and percentage mortality to achieve normality and allow for parametric tests.

A comparison of the types of damage between sites was made using the Bray-Curtis Index of similarity and MDS analysis. The data for percentage mortality was 4 th root-transformed. An analysis of similarities (ANOSIM; Clarke \& Ainsworth, 1988) was also carried out on the rank similarity matrix to test for significant difference between sites.

\section{RESULTS}

\section{Benthic coral cover and diversity}

There were several differences in the substratum at the three sites in hard coral cover and frondose algae cover (Table 1). There was greater coral abundance in MMNP than Nyali or Ras Iwatine, the average percentage coral cover at the three sites being $23.6 \pm 9.7$ (mean \pm SD), $5.5 \pm 3.6$ and 13.9 \pm 5.4 respectively. Mombasa Marine National Park

Table 1. Topographic complexity (rugosity), diversity (Simpson's index, $D$ ) of hard coral and average percentage cover (mean \pm SD) of substrata categories at the three sites

\begin{tabular}{lccc}
\hline & MMNP & Ras Iwatine & Nyali \\
\hline Transects $(\mathrm{n}=)$ & 18 & 12 & 9 \\
Total transect length $(\mathrm{m})$ & 180 & 120 & 90 \\
Topographic complexity & $1.3 \pm 0.1$ & $1.2 \pm 0.1$ & $1.2 \pm 0.0$ \\
Hard Coral Diversity $(D)$ & 0.70 & 0.80 & 0.81 \\
Hard coral & $23.6 \pm 9.7$ & $5.5 \pm 3.6$ & $13.9 \pm 5.4$ \\
Algal turf & $48.5 \pm 10.1$ & $44.9 \pm 15.5$ & $32.3 \pm 11.5$ \\
Calcareous green algae & $0.4 \pm 0.7$ & $0.9 \pm 1.2$ & $8.0 \pm 4.1$ \\
Frondose algae & $1.7 \pm 1.3$ & $22.5 \pm 9.0$ & $32.2 \pm 12.3$ \\
Coralline red algae & $13.9 \pm 5.9$ & $10.3 \pm 8.1$ & $8.3 \pm 3.0$ \\
Seagrass & 0.0 & $6.2 \pm 4.5$ & 0.0 \\
Soft coral & $2.0 \pm 1.9$ & $1.0 \pm 1.1$ & $1.2 \pm 1.4$ \\
Sand & $8.4 \pm 7.5$ & $6.4 \pm 2.0$ & $3.4 \pm 4.0$ \\
Sponge & $1.4 \pm 1.2$ & $2.3 \pm 2.1$ & $0.7 \pm 1.1$ \\
\hline
\end{tabular}


also had the lowest frondose algal cover of the three sites. The Shannon index for hard corals was calculated for the three sites and was very similar for the three sites, with MMNP $=0.81$, Nyali $=$ 0.70 , and Ras Iwatine $=0.80$ respectively.

\section{Control vs experimental colonies/ transplants}

There was a significant difference between the experimental and caged control transplants at the two sites without beach seining, Ras Iwatine and MMNP (Mann-Whitney U test; MMNP/ branching $\mathrm{n}=6, \mathrm{~W}=51.0, \mathrm{P}=0.03$; massive $\mathrm{n}=6, \mathrm{~W}=$ 55.5, $\mathrm{P}=0.005$; and Ras Iwatine/branching $\mathrm{n}=6$, $\mathrm{W}=55.0, \mathrm{P}=0.006$; massive $\mathrm{n}=6, \mathrm{~W}=51.0, \mathrm{P}=$ 0.033). Corals outside the cages suffered significantly higher mortality than corals inside the cages, indicating that cages successfully controlled predation. There was, however, no significant difference between controls and experimental colonies for both branching $(\mathrm{n}=9, \mathrm{~W}=92.0, \mathrm{P}=$ $0.29)$ and massive corals $(\mathrm{n}=9, \mathrm{~W}=100.0, \mathrm{P}=$ 0.11 ) at the beach-seining site, Nyali. This occurred because beach seines pulled up four cages in Nyali and either broke or dislodged the controls (only the bases were left). Cages were thus not an effective means of control against beach seining and a similar mortality rate was found for the experimental and control colonies.

\section{Percentage mortality by location, species and size}

There was a significant difference in percentage mortality between sites for Porites palmata (ANOVA df $=2, \mathrm{~F}=11.1, \mathrm{P}=0.001$ ). $\mathrm{MMNP}$ suffered the most damage with $39.5 \%( \pm 4.9)$ mortality, followed by Nyali with $31.0 \%$ ( \pm 6.5$)$ and Ras Iwatine with $16.8 \%( \pm 6.4)$ mortality. Pair-wise comparisons indicated that the main difference lay between MMNP and Ras Iwatine (Fig. 2). There was no significant difference in percentage mortality between sites for Porites lutea (ANOVA df $=2, \mathrm{~F}=$ $0.71, \mathrm{P}=0.51)$, with all sites suffering similarly low mortality: MMNP-9.1\% ( \pm 5.3), Nyali-13.6\% ( \pm $5.4)$, Ras Iwatine-13.5\% ( \pm 6.4$)$. There was a significant relationship between coral morphology and site $(\mathrm{df}=2, \mathrm{~F}=8.4, \mathrm{P}=0.01)$-branching transplants generally suffered greater damage.
There was no significant correlation between percentage mortality and size for either the branching (ANCOVA df $=2, \mathrm{~F}=0.42, \mathrm{P}=0.52$ ) or massive Porites (ANCOVA df $=2, \mathrm{~F}=0.31, \mathrm{P}$ $=0.58)($ Fig. $3 a$ and $b)$.

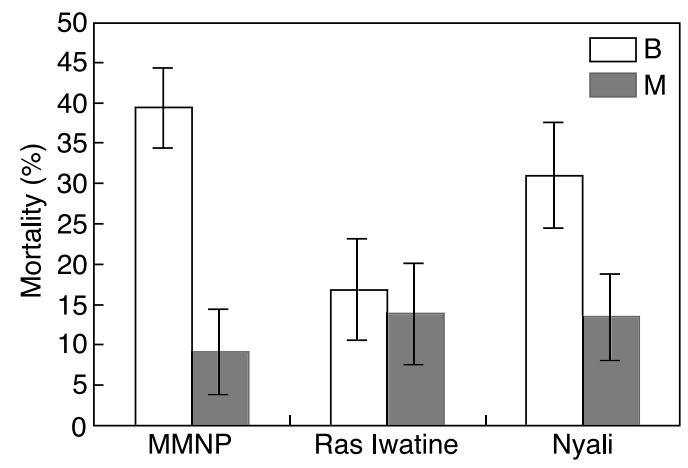

Fig. 2. Percentage mortality between sites for branching (B) and massive (M) Porites. Bars represent $95 \%$ C.I.

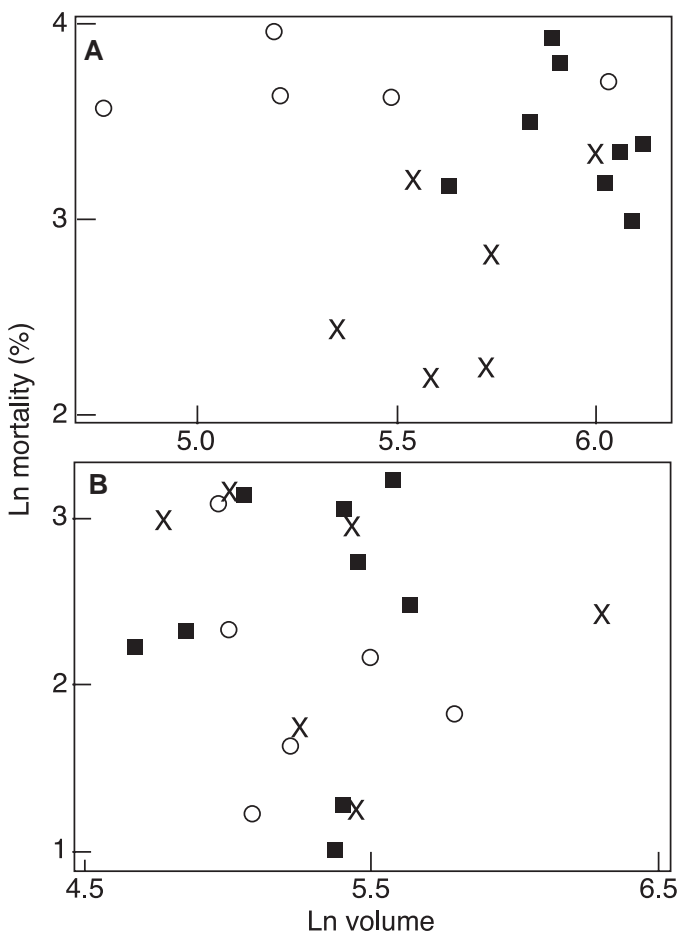

Fig. 3. Correlation between size (volume) and percentage mortality of (A) branching and (B) massive Porites at the three study sites. Filled squares represent average volume of corals in one 'block' against percentage mortality of the same corals at Nyali $(n=9)$. Circles represent MMNP $(n=6)$ and crosses Ras Iwatine $(n=6)$. 


\section{Difference in types of damage}

There was a significant difference in the type of damage between sites for Porites palmata (ANOSIM R $=0.36, \mathrm{P}=0.001$ ). The MDS plot (Fig. 4A) provides a graphical illustration of the relative similarity in the types of damage suffered by each block at each site. There was a significant difference in damage composition (type) at the three sites (Table 2, ANOSIM pair-wise test). The main types of damage were predation by fish, predation by gastropods (only at MMNP) and beach seining (Fig. 5).

The extent of damage from predation was significantly different between the three sites for Porites palmata (ANOVA df $=2, \mathrm{~F}=5.24, \mathrm{P}=$ $0.016)$, with MMNP being most affected with $31.0 \%$ mortality, followed by Nyali with $24.3 \%$ and Ras Iwatine with $13.8 \%$ mortality. This difference was significant between MMNP and Ras Iwatine but not between Nyali and MMNP (Tukey

Table 2. ANOSIM pairwise test for difference in types of damages for branching Porites between sites. The damage was significantly different between the three sites $(P<0.05)$

\begin{tabular}{lcc}
\hline Sites & $\mathrm{R}$ & $\mathrm{P}$ \\
\hline Nyali/MMNP & 0.36 & 0.008 \\
Nyali/Ras Iwatine & 0.27 & 0.025 \\
MMNP/Ras Iwatine & 0.45 & 0.004 \\
\hline
\end{tabular}
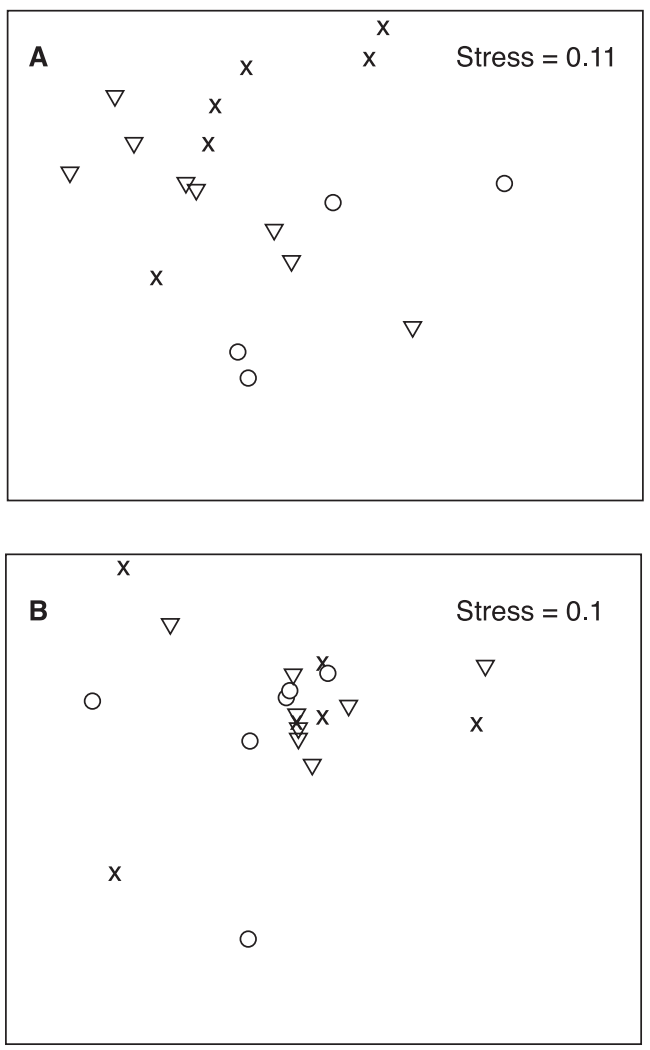

Fig. 4. MDS ordination plot based on Bray-Curtis similarities showing the damage composition to (a) branching and (b) massive Porites at MMNP, Nyali and Ras Iwatine $(n=9$ for Nyali, $n=6$ for MMNP, $n=6$ for Ras Iwatine). Circles represent MMNP, inverted triangles Nyali, and crosses Ras Iwatine.

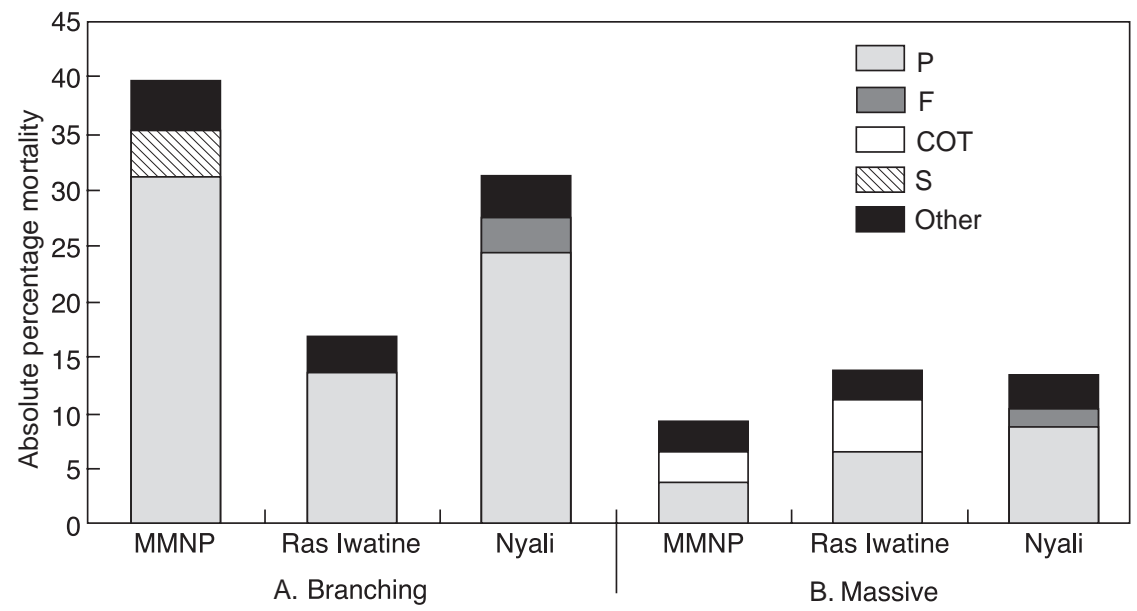

Fig. 5. Absolute percentage mortality of (A) branching and (B) massive Porites due to different types of damage at the three sites. P, predation by fish; F, fishing; COT, crown-of-thorns; S, snail; 'other' includes transplantation, sand, sponge and unidentified damage 
post hoc, $\mathrm{P}<0.05)$. Fishing was only responsible for $3.2 \%$ mortality (Fig. 5). Damage from beach seining was therefore less important than damage by predators at all sites.

There was no significant difference in the type of damage between sites for Porites lutea (ANOSIM R $=0.09, \mathrm{P}=0.12$ ). The MDS plot (Fig. 4B) provides a graphical illustration of the relative similarity in the types of damage suffered by each block at each site. The difference in composition of damage was not significant between the three sites (ANOSIM pair-wise test). Damage by predators was not significantly different between the three sites for Porites lutea (ANOVA df $=2, \mathrm{~F}$ $=1.73, \mathrm{p}=0.21)$ (Fig. 5).

\section{DISCUSSION}

\section{Massive vs branching corals}

Branching morphologies are usually used in experiments on coral regeneration for two main reasons: they have a life history with high asexual reproduction by fragmentation (Highsmith, 1982; Hughes, 1985; Bruno, 1998), and have rapid growth and regeneration (Done, 1982; Karlson \& Hurd, 1993). They are also more fragile than other morphologies, often suffering the most damage from hurricanes and wave action, bleaching (McClanahan, 2000), COTs predation (Brown, 1997, Edinger \& Risk, 2000) or human disturbances such as diving (Rouphael \& Inglis, 1997, 2002; Hawkins et al., 1999; Jameson et al., 1999), fishing (Edinger \& Risk, 2000), and transplantation (Edwards \& Clark, 1998). However, in this study the branching and massive morphologies did not show differences in percentage mortality due to beach seining. This may be due to the short time period of the experiment. The vertical arborescent structure of branching $P$. palmata was expected to be snagged, dislodged or damaged by seine net fishing to a greater extent than the spherical or horizontal encrusting structure of $P$. lutea.

Porites palmata was more susceptible to fish predation than the massive species. Massive corals are thus recommended for transplantation due to their low damage and mortality and may ultimately produce the habitat required for fish and other coral morphologies. This finding is supported by Edwards \& Clark (1998), who contend that mortality in branching species is too high to justify the effort of transplantation. Crame (1981) argued, from observations on fossil corals, that massive Porites constitutes a foundation taxon on which a succession of other members of the coral community is dependent. However, massive morphologies found in the Caribbean such as Montastrea annularis, Montastrea faveolata and Colpophylla natans seem to be the common food of parrotfish (Bythell et al., 1993; Bruckner \& Bruckner, 1998). Therefore, in areas where there are large parrotfish, massive Porites may be more affected by predation than branching corals.

\section{Fishing vs the effect of predators on branching Porites}

Beach seining is classified as destructive form of fishing due to the physical contact and potential damage to the benthic community (Jennings \& Kaiser, 1998). Nevertheless, less damage was recorded from beach seining than corallivory by fish in our short study. Although beach seining occurred every day we were present at the two Nyali sites, the frequency of actual impact with corals may have been low, but when contact did occur it was damaging. This is comparable to frequent, but often minor, damage by fish. Damage by fish is frequent and therefore statistically more likely to be encountered while the opposite is true of seine netting. Short-term measurements may, therefore, underestimate the long-term impacts of beach seining.

Marine parks increase fish biomass, abundance and diversity (McClanahan et al., 1999; Mosquera et al., 2000; Côté et al., 2001, McClanahan \& Arthur, 2001; McClanahan \& Mangi, 2001). Fish abundance in the established parks in Kenya, including Mombasa Marine National Park, is about 3.5 times higher than the abundance on adjacent fished reefs (McClanahan et al., 1999). This includes parrotfish, triggerfish and butterflyfish, all of which prey on corals (Hixon, 1997; Miller \& Hay, 1998). Consequently, greater damage from predation is likely to occur inside no-fishing marine parks but we found this only for branching and not the massive forms of Porites. 
The coral reefs in Nyali were inhabited by smaller fish than in MMNP (McClanahan \& Mangi, 2001). In MMNP, parrotfish 'spot biting' (Bruckner et al., 2000) was often recognisable on the transplants, especially the massive species. Fish bites were less noticeable in Nyali. During this study, no large fish were observed at Nyali (A. Cros, pers. obs.), as is often the case in overexploited reefs (Jennings \& Kaiser, 1998). This leads to the hypothesis that, although fish were smaller in Nyali, they concentrated their predation on the transplanted massive corals due to the lack of corals occurring naturally thereby elevating the measured predation level. This hypothesis requires further testing. This contrasts with MMNP where fish were larger and more abundant but had more choice of coral to prey on.

Branching coral transplants suffered the least damage at Ras Iwatine. Unlike the preceding two sites, very few fish were observed preying on or near the transplanted corals (A. Cros, pers. obs.). On the other hand, a large number of sea urchins were observed near or on coral transplants (A. Cros, pers. obs.). Fishing and sea urchin dominance may effectively maintain low fish populations on overexploited reefs (McClanahan, 1994a; McClanahan \& Arthur, 2001; McClanahan \& Mangi, 2001), especially parrotfish (McClanahan, 1994a). Sea urchins are grazers and are usually responsible for the bio-erosion of coral skeletons once corals die and become overgrown by algae (Jennings \& Kaiser, 1998). The low fish abundance explains the low predation level and overall low damage level at this site.

\section{Invertebrate corallivores}

In the last weeks of monitoring, the coral-eating snail Drupella cornus was found on one block of transplants preying on Porites palmata in the vicinity of a large patch of dead Acropora in MMNP. There were three to four snails on each branching coral and they killed $60 \%$ of each colony/transplant, mostly at the base. This was similar to previous observations of $D$. cornus preying on the genus Acropora and the family Pocilloporidae (McClanahan, 1994b; Turner, 1994a, b) on damaged reefs in Kenya and western Australia (Turner, 1994a, b). In the past, damage by Drupella outbreaks has been compared to damage by crown-of-thorns (COTs) outbreaks (Cumming, 1999). Reports of mass mortality due to this snail have been recorded in Western Australia and Japan (Turner, 1994a,b). Outbreaks have been in part attributed to over fishing and the removal of key predators of the snail (Turner, 1994a, b; McClanahan, 1994b). A further investigation on Drupella outbreaks should be considered.

\section{Future perspectives}

In the long term it is necessary to consider both the direct and indirect effects of beach seining to get a broader picture of its effects on corals. Dislodgement and damage from beach seining is likely to increase the chances of coral mortality. Dead colonies have been found to maintain their function as habitat for fishes and to facilitate larval and juvenile settlement (Lindahl et al., 2001), but rubble, which can be created by beach seining, causes further damage to neighbouring corals (Lindahl, 1998; Bowden-Kerby, 2001; Precht et al., 2001). Furthermore, if high densities of fish in MMNP are responsible for coral damage by predation, they also were associated with high coral abundance as determined by the line-transect studies. Miller \& Hay (1998) argue that there may be a fine balance between the provision of habitat and damage to corals for certain species, but nevertheless there is a strong correlation between high coral abundance and fish density (Bell \& Galzin, 1984; Chabanet et al., 1997), especially in the MMNP(McClanahan \& Arthur, 2001). Grazing fish are essential to maintain low algal abundance and to promote coral growth. In reef environments like Nyali or Ras Iwatine with low densities of grazers, damaged corals are likely to be quickly overgrown by algae and experience further tissue loss (Carreiro-Silva \& McClanahan, 2001).

Surprisingly, and contrary to predictions, coral transplants in this study were more affected by fish corallivory inside a no-fishing MPA. Porites palmata manifested a significant difference in damage between the three management regimes, unlike the massive morphology that seemed less susceptible to corallivory, but showed no difference in the direct impacts of beach seining. However, 
due to the limited time scale of this study and low site replication, it is difficult to draw definitive conclusions about the long-term effects of beach seining on corals and further long-term and betterreplicated studies are recommended.

Acknowledgments-This study received financial support from the Department of Marine Sciences and Coastal Management of the Faculty of Agriculture and Biological Sciences in the University of Newcastle-upon-Tyne, the Exploration Council and the Wildlife Conservation Society. The Coral Reef Conservation Project (CRCP) and the Kenyan Wildlife Services (KWS) provided logistical support, materials, and information needed to carry out this project. We thank Joseph Maina, Steve Mangi, and Moses Mwambogo for their invaluable field assistance and guidance through the CRCP library and all the coxswains of KWS for endless hours of support on the reef. Discussion and guidance from Dr J. Bythell was very helpful.

\section{REFERENCES}

Allison, G.W., Lubchenco, J. \& Carr, M.H. (1998) Marine reserves are necessary but not sufficient for marine conservation. Ecol. Appl. 8: S79-S92.

Bell, J.D. \& Galzin, R. (1984) Influence of live coral cover on coral-reef fish communities. Mar. Ecol. Prog. Ser. 15: 265-274.

Bowden-Kerby, A. (2001) Low-tech coral reef restoration methods modelled after natural fragmentation processes. Bull. Mar. Sci. 69: 915931.

Brown, B.E. (1997) Disturbances to reefs in recent times. In: Birkeland, C. (ed) Life and death of coral reefs. Chapman \& Hall, New York. pp. 354-379.

Bruckner, A.W. \& Bruckner, R.J. (1998) Destruction of corals by Sparisoma viride. Coral Reefs 17: 350.

Bruckner, A.W., Bruckner, R.J. \& Sollins, P. (2000) Parrotfish predation on live coral: "spot biting" and "focused biting". Coral Reefs 19: 50.

Bruno, J.F. (1998) Fragmentation in Madracis mirabilis (Duchassaing and Michelotti): how common is size-specific fragment survivorship in corals? J. Exp. Mar. Biol. Ecol. 230: 169-181.

Bythell, J.C., Gladfelter, E.H., \& Bythell, M. (1993) Chronic and catastrophic natural mortality of three common Caribbean reef corals. Coral Reefs 12: 143-152.
Carreiro-Silva, M. \& McClanahan, T.R. (2001) Echinoid bioerosion and herbivory on Kenyan coral reefs: the role of protection from fishing. $J$. Exp. Mar. Biol. Ecol. 262: 133-153.

Chabanet, P., Ralambondrainy, H., Amanieu, M., Faure, G. \& Galzin, R. (1997) Relationships between coral reef substrata and fish. Coral Reefs 16: $93-102$.

Clarke, K.R. \& Ainsworth, M. (1988) A method of linking multivariate community structure to environmental variables. Mar. Ecol. Prog. Ser. 92: 205-219.

Côté, I.M., Mosquera, I. \& Reynolds, J.D. (2001) Effects of marine reserve characteristics on the protection of fish populations: a meta-analysis. $J$. Fish. Biol. 59: 178-189.

Cox, E.F. (1986) The effects of a selective corallivore on growth-rates and competition for space between 2 species of Hawaiian corals. J. Exp. Mar. Biol. Ecol. 101: 161-174.

Crame, J. A. (1981) Ecological stratification in the Pleistocene coral reefs of the Kenya Coast. Palaeontology 24: 609-646.

Cumming, R.L. (1999) Predation on reef-building corals: multiscale variation in the density of three corallivorous gastropods, Drupella spp. Coral Reefs 18: 147-157.

Done, T.J. (1982) Patterns in the distribution of coral communities across the central Great Barrier Reef. Coral Reefs 1: 95-107.

Dusek, E. (2000) Effects of fishing gear on coral reef recovery in Kenya following 1998 El Niño induced coral bleaching. Honors Program, Stanford University, Palo Alto, Ca.

Edinger, E.N. \& Risk, M.J. (2000) Reef classification by coral morphology predicts coral reef conservation value. Biol. Cons. 92: 1-13.

Edwards, A.J. \& Clark, S. (1998) Coral transplantation: a useful management tool or misguided meddling? Mar. Pollut. Bull. 37: 474-487.

Hawkins, J.P., Roberts, C.M., Van't Hof, T., de Meyer, K., Tratalos, J. \& Aldam, C. (1999) Effects of recreational scuba diving on Caribbean coral and fish communities. Biol. Cons. 13: 888-897.

Highsmith, R.C. (1982) Reproduction by fragmentation in corals. Mar. Ecol. Prog. Ser. 7: 207-226.

Hixon, M.A. (1997) Effects of reef fishes on corals and algae. In: Birkeland, C. (ed) Life and death of coral reefs. Chapman \& Hall, New York. pp. 232-248.

Hughes, T.P. (1985) Life histories and population dynamics of early successional corals. Proc. 5th Int. Coral Reef Congr. 4: 101-106.

Jameson, S.C., Ammar, M.S.A., Saadalla, E., Mostafa, H.M. \& Riegl, B. (1999) A coral damage index and its application to diving sites in the Egyptian 
Red Sea. Coral Reefs 18: 333-339.

Jennings, S. \& Kaiser, M.J. (1998) The effects of fishing on marine ecosystems. Adv. Mar. Biol. 34: 291-302.

Jennings, S. \& Polunin, N.V.C. (1996) Impacts of fishing on tropical reef ecosystems. Ambio 25: 44-49.

Karlson, R.H. \& Hurd, L.R. (1993) Disturbance, coral reef communities, and changing ecological paradigms. Coral Reefs 12: 177-125.

Lindahl, U. (1998) Low-tech rehabilitation of degraded coral reefs through transplantation of Staghorn corals. Ambio 27: 645-648.

Lindahl, U., Öhman, M.C. \& Schelten, C.K. (2001) The 1997/1998 mass mortality of corals: effects on fish communities on a Tanzanian coral reef. Mar. Poll. Bull. 42: 127-131.

McClanahan, T.R. (1994a) Kenyan coral reef lagoon fish: effects of fishing, substrate complexity, and sea urchins. Coral Reefs 13: 231-241.

McClanahan, T.R. (1994b) Coral-eating snail Drupella cornus population increases in Kenyan coral reef lagoons. Mar. Ecol. Prog. Ser. 115: 131-137.

McClanahan, T.R. (2000) Bleaching damage and recovery potential of Maldivian coral reefs. Mar. Poll. Bull. 40: 587-597.

McClanahan, T.R. \& Arthur, R. (2001) The effect of marine reserves and habitat on populations of East African coral reef fishes. Ecol. Appl. 11: 559-569.

McClanahan, T.R. \& Mangi, S. (2001) The effect of a closed area and beach seine exclusion on coral reef fish catches. Fish. Manage. Ecol. 8: 107-121.

McClanahan, T.R., Muthiga, N.A., Kamukuru, A.T., Machano, H. \& Kiambo, R.W. (1999) The effects of marine parks and fishing on coral reefs of northern Tanzania. Biol. Cons. 89: 161-182.

McClanahan, T.R., Muthiga, N.A. \& Mangi, S. (2001) Coral and algal changes after the 1998 coral bleaching: interaction with reef management and herbivores on Kenyan reefs. Coral Reefs 19: 380391.

McClanahan, T.R. \& Shafir, S.H. (1990) Causes and consequences of sea urchin abundance and diversity in Kenyan coral reef lagoon. Oecologia 83: $362-370$.

Miller, M.W. \& Hay, M.E. (1998) Effects of fish predation and seaweed competition on the survival and growth of corals. Oecologia 113: 231-238.

Mosquera, I., Côté, I.M., Jennings, S. \& Reynolds, J.D. (2000) Conservation benefits of marine reserves for fish populations. Anim. Cons. 3: 321332.

Obura, D.O. (2001) Kenya. Mar. Poll. Bull. 42: 12641278.

Precht, W.F., Aronson, R.B., \& Swanson, D.W. (2001) Improving scientific decision-making in the restoration of ship-grounding sites on coral reefs. Bull. Mar. Sci. 69: 1001-1012.

Rouphael, A.B. \& Inglis, G.J. (1997) Impacts of recreational scuba diving at sites with different reef topographies. Biol. Cons. 82: 329-336.

Rouphael, A.B. \& Inglis, G.J. (2002) Increased spatial and temporal variability in coral damage caused by recreational scuba diving. Ecol. Appl. 12: 427440

Turner, S.J. (1994a) The biology and population outbreaks of the corallivorous gastropod Drupella on Indo-Pacific reefs. Oceanogr. Mar. Biol. Annu. Rev. 32: 461-530.

Turner, S.J. (1994b) Spatial variability in the abundance of the corallivorous gastropod Drupella cornus. Coral Reefs 13: 41-48.

Zar, J.H. (2000) Biostatistical analysis. Prentice Hall, New Jersey. 